\title{
Primary Succession along an Elevation Gradient 15 Years after the Eruption of Mount Pinatubo, Luzon, Philippines ${ }^{1}$
}

\author{
Thomas E. Marler ${ }^{2,4}$ and Roger del Moral ${ }^{3}$
}

\begin{abstract}
We determined vegetation structure and environmental variables in the Pasig-Potrero and Sacobia River systems on the east flank of Mount Pinatubo, Luzon, Philippines, to define growth form and taxonomic groups that have influenced primary succession during the $15 \mathrm{yr}$ since the eruption. We selected eight sites within an east-west range of $11.5 \mathrm{~km}$, a north-south range of $7 \mathrm{~km}$, and an elevation gradient of ca. $500 \mathrm{~m}$. The 58 plant taxa we encountered among 63 sampled plots belonged to 21 families. Cover was dominated by Parasponia rugosa (tree) and Saccharum spontaneum (large grass). Cover of these two species was inversely related at the plot level. Exotic species represented nearly $60 \%$ of this flora but only $32 \%$ of the vegetation cover. Family richness was high for Asteraceae, Fabaceae, and Poaceae. Elevation, distance to the caldera, and distance to human settlement exhibited the most control over the vegetation. The influence of elevation on cover, species composition, and structure differed in these adjacent canyons. Plot species richness, cover, and diversity indices were greatest at the highest elevation of the Pasig-Potrero River. On a small scale, current dominant species may control progression of species assemblages as mediated by geophysical, chemical, facilitative, and competitive changes. Our findings indicate that ongoing anthropogenic disturbances and the prevalence of exotic species may prevent the vegetation from returning to its preeruption state. The invasive Pennisetum setaceum and Chromolaena odorata were widespread in this landscape, and their negative influence on vegetation recovery is probable. Ours is the first detailed survey of vegetation on newly created volcanic surfaces in the region and provides a baseline for understanding the landscape-level processes determining continuing succession.
\end{abstract}

Mount Pinatubo, Luzon Island, Philippines, erupted on 15 June 1991, wreaking widespread havoc and altering global climate. Between 5 and $6 \mathrm{~km}^{3}$ of ejecta were deposited on the upper slopes (Newhall and Punongbayan 1996). Pyroclastic flows filled the val-

\footnotetext{
${ }^{1}$ Funding provided by the Western Pacific Tropical Research Center (TEM) and U.S. NSF Grant no. DEB 05-41972 (RdM). Manuscript accepted 16 May 2010.

${ }^{2}$ College of Natural and Applied Sciences, University of Guam, Mangilao, Guam 96923.

${ }^{3}$ Department of Biology, University of Washington, Seattle, Washington 98195-1800.

${ }^{4}$ Correspondending author (phone: 671-735-2130; e-mail: tmarler@uguam.uog.edu).
}

Pacific Science (2011), vol. 65, no. 2:157-173

doi: $10.2984 / 65.2 .157$

(C) 2011 by University of Hawai'i Press

All rights reserved leys that radiate from the summit to depths up to $200 \mathrm{~m}$ and covered over $30 \%$ of their watersheds (Major et al. 1996). Tephra blanketed the upper watersheds, but it was subsequently redeposited by over 200 lahars during the 1991 rainy season alone (Pierson et al. 1996). Lahar frequency declined over time but continued during typhoons for more than a decade.

A natural disturbance of this magnitude presents a rare opportunity to study plant succession. For example, some of the factors that govern community assembly may be scrutinized because some surfaces are recovering from a completely barren start. The initial colonists that define vegetation assembly at small scales provide taxa interactions that may illuminate our understanding of how competition, facilitation, and mutualisms influence stages of succession. In the case of Mount 
Pinatubo, the prevalence and duration of lahars, landslides along the unstable canyon walls, and shifting surfaces due to highdischarge events like typhoons provide opportunities to study repeated disturbances that, in some cases, effectively reset primary succession at the fine scale.

Most studies of this stratovolcano eruption described its global climatic effects (e.g., Forster and Collins 2004, Douglass and Knox 2005) or have focused on substrate properties and recovery (e.g., Sasaki et al. 2003, Gran and Montgomery 2005). Some of the few biological studies provided general observations on vegetation, but no study has yet detailed the plants recolonizing the posteruption surfaces or factors that explain vegetation patterns. Numerous publications describing the "Pinatubo effect" included vegetation responses around the globe. For example, Gu et al. (2003) used data from a temperate forest to determine that Mount Pinatubo aerosols increased diffuse radiation that enhanced terrestrial ecosystem productivity and contributed to the temporary decline of increasing carbon dioxide concentration in the atmosphere. In this light, the absence of publications on vegetation recovery within Mount Pinatubo's own landscape is conspicuous.

Among regional volcanoes, only studies of Krakatau (Whittaker et al. 1989, Thornton 1996) and Mot Mot (Thornton 2007) stand out as providing meaningful ecological insight. The long record of observation and high diversity make the Krakatau island group a center of biogeographic and successional investigation (Whittaker et al. 1992) as well as having provided critical insights into how dispersal limitations alter succession trajectories and the assembly of mature vegetation (Whittaker and Jones 1994, Whittaker and Fernández Palacios 2007). However, those studies were conducted in dramatically different biological contexts (e.g., very few exotic species), and initial processes were observed only qualitatively.

To address the vacuum of information, we describe the vegetation along two river canyons on the east flanks of Mount Pinatubo. Our objectives were to determine the manner in which elevation influenced cover of indi- vidual taxa and growth form categories. We hypothesized that any dissimilarities between the canyons could be explained by differences in elevation range, status of recovery of geophysical surface stability, and magnitude of ongoing anthropogenic disturbance. We determined a short list of landscape characteristics that have controlled early primary succession, and clarified the plant and landscape-mediated processes that are probable harbingers of future succession.

\section{MATERIALS AND METHODS}

\section{Field Sampling}

We explored the Pasig-Potrero River (PR) and Sacobia River (SR) in early 2006 (Luzon, Philippines, latitude $15^{\circ} 08^{\prime} 08^{\prime \prime}$ to $15^{\circ} 11^{\prime} 43^{\prime \prime}$ $\mathrm{N}$, longitude $120^{\circ} 23^{\prime} 40^{\prime \prime}$ to $120^{\circ} 30^{\prime} 15^{\prime \prime} \mathrm{E}$ ) (Figure 1) to determine the range of habitats being colonized. We defined the extent of this study by establishing the lower bound of the survey as the partially vegetated floodplains immediately below the new alluvial fan (ca. $200 \mathrm{~m}$ above sea level [asl]). We then reconnoitered up the canyons toward the caldera until we encountered impassable terrain, which defined the upper boundary of our survey in each canyon. This occurred at about $750 \mathrm{~m}$ asl on PR, where a waterfall overflowing a narrow constriction prevented our further ascent, and at the head of the canyon of SR (ca. $450 \mathrm{~m}$ asl), where the genesis of the channel is formed by several springs. We used an altimeter to mark sites at approximately $100 \mathrm{~m}$ elevation increments to define five locations on the PR and three on the SR. Precise elevations of each plot were later determined from GPS positions and topographic maps. The study encompassed an altitudinal range of $540 \mathrm{~m}$, an east-west range of about $11.5 \mathrm{~km}$, and a north-south range of $7 \mathrm{~km}$.

Vegetation was sampled during the dry season of February-April 2006. The number of plots at each location was defined by available vegetated surfaces. Our intent was to create an inventory of the taxa and determine how they have assembled to provide a baseline for meaningful studies of succession. 


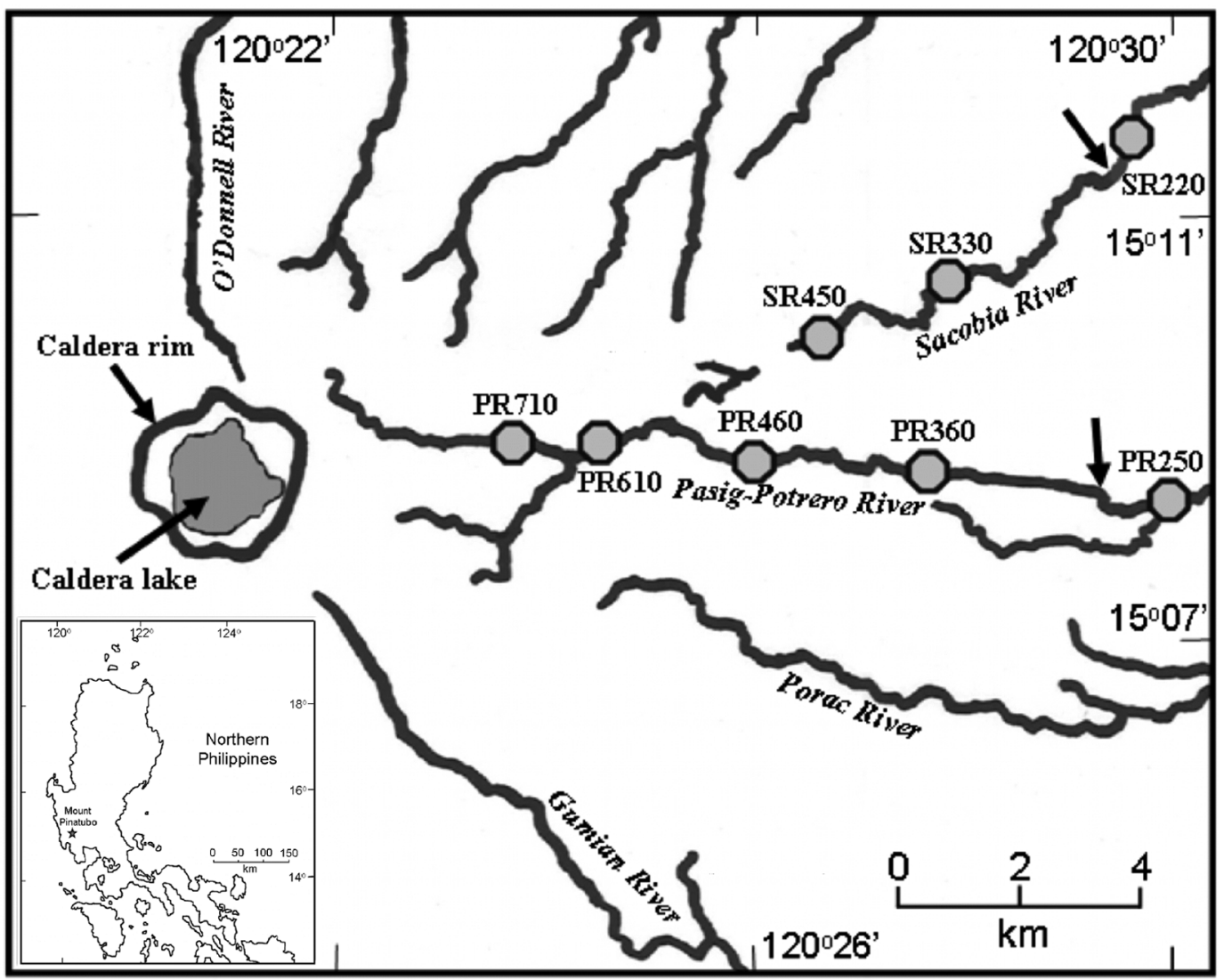

Figure 1. Inset shows location of Mount Pinatubo, Luzon, Philippines. The expanded location map shows study sites on Mount Pinatubo. Circles are field locations of plots in which vegetation cover was determined along Sacobia (SR) and Pasig-Potrero (PR) River canyons. Numbers are the mean elevation of plots within each location. Arrows on each river designate the location of the alluvial fan. Thick lines are either rivers or the caldera rim.

Therefore, we sampled 63 plots among the eight sites (Figure 1), using 12 quadrats per plot following del Moral and Lacher (2005). Whenever possible, we used circular $250 \mathrm{~m}^{2}$ plots as follows: from the center of the plot, three $1 \mathrm{~m}^{2}$ quadrats were arrayed at $2 \mathrm{~m}$ intervals along radii arrayed along the cardinal directions. Some of the heavily vegetated sites were narrow, so we used $25 \mathrm{~m}$ transects with $1 \mathrm{~m}^{2}$ quadrats placed every $2 \mathrm{~m}$ on alternate sides. Total quadrat area was $12 \mathrm{~m}^{2}$ for each plot. Percentage cover was estimated visually for each species by a vertical projection of their canopies in each of the 12 quadrats. Therefore, total plot cover could exceed $100 \%$.
We determined slope of each plot with an inclinometer and aspect with a compass. General soil-surface morphology was quantified by estimating the percentage of the surface covered by rocks. We measured the lateral distance between the center of each plot and the edge of the canyon or the running channel. We used plot positions and maps to determine the lateral distance between each plot and the nearest edge of the caldera and the alluvial fan.

T.E.M. identified most species during the survey. Unidentified taxa were photographed and cataloged by their local Aeta, Kapampangan, or Tagalog name. Most were identified by cross-references to the English and scien- 
tific names (e.g., Madulid 2001). Identification of the remaining taxa was secured by providing relevant taxonomic experts with photographs and field data. Their tentative identifications were confirmed in situ during subsequent field visits using their diagnostic information. Nomenclature conformed to the International Plant Names Index Web site (2009), except that Parasponia rugosa Blume (formerly Trema philippinensis Elm.) follows USDA Germplasm Resources Information Network (2009). We grouped taxa into seven growth forms to determine the contribution of each to vegetation cover (see Appendix).

\section{Vegetation Structure and Analytical Methods}

Species richness (the number of species in the plot); total percentage cover (sum of the cover of species in the plot); Simpson's diversity index $\left(\mathrm{D}=\left[1-\Sigma p_{i}^{2}\right]\right)$, and Shannon diversity $\left(\mathrm{H}^{\prime}=\left[-\Sigma p_{i} \log p_{i}\right]\right)$ were calculated for each plot. $\mathrm{D}$ and $\mathrm{H}^{\prime}$ were calculated from $p_{i}$, the proportion of the cover represented by $i$ th species. We included both measures of diversity to maximize comparisons with other studies. We tested the hypothesis that differences in these variables occurred among the rivers and plot elevations using multivariate analysis of variance (ANOVA). Highly significant differences occurred among the locations. Highly significant correlations occurred between richness and $\mathrm{D}$, richness and $\mathrm{H}^{\prime}$, and $\mathrm{D}$ and $\mathrm{H}^{\prime}$. Therefore, we then used one-way univariate ANOVA for each variable to determine differences among the eight locations or differences between the two rivers. Least Squares was used to define groups of locations that were not different for each significant variable.

The mean absolute cover of each species in a plot was the average cover in the 12 quadrats. We assigned each species to one of the following growth form categories: trees, shrubs, large grasses, small graminoids, vines, forbs, and ferns. We tested the hypothesis that differences in cover of individual species and growth form categories occurred among locations using one-way ANOVA, then employed the conservative Bonferroni statistic for separating locations for significant variables.

Multiple linear regression models were fitted to test the hypothesis that environmental variables (elevation; percentage rock cover; slope; aspect; and distance to running channel, canyon edge, permanent human settlement, alluvial fan, and caldera) significantly influenced vegetation cover, richness, $\mathrm{D}$, and $\mathrm{H}^{\prime}$. Partial regression coefficients were generated to define the positive or negative relationships.

\section{RESULTS}

\section{Floristics and Vegetation Structure}

Our inventory of 58 taxa included 21 plant families (Appendix). Asteraceae, Fabaceae, and Poaceae had the greatest family richness, with each represented by 10 or more species. In contrast, 15 families were represented by a single species. Ficus was the only genus represented by three species, and most genera were represented by a single species. More than $70 \%$ of the species occurred in both river canyons. We encountered 52 species in the PR and 45 in the SR. There were 34 exotic species and 24 native species.

Mean richness of the eight sites ranged from 7.7 to 16.5 species per plot $(F=9.67$, edf $=55, P<.0001$ [Table 1]). Richness was lowest in middle-elevation plots of the PR and greatest at the highest elevation of the PR. Mean plot richness in PR was lower than that of SR (PR, 10.7 species; SR, 13.2 species; $t=-2.25, P<.0095)$. Mean percentage cover of combined PR sites did not differ from that of SR sites (PR, 134.6\%; SR, 121.8\%), but cover differed among the locations $(F=2.67$, edf $=55, P<.0188)$. Cover was greatest at the highest site of the PR and lowest at the highest site on the SR.

Shannon diversity $\left(\mathrm{H}^{\prime}\right)$ ranged from 1.180 to $1.972(F=9.26$, edf $=55, P<.0001)$, separated into three groups, and varied more among PR than among SR sites (Table 1). It is interesting that the greatest $\mathrm{H}^{\prime}$ occurred at the highest PR location and the lowest SR location. The overall mean was higher on the $\mathrm{SR}$ than on the PR $(\mathrm{t}=-3.38, P<.0001)$. 


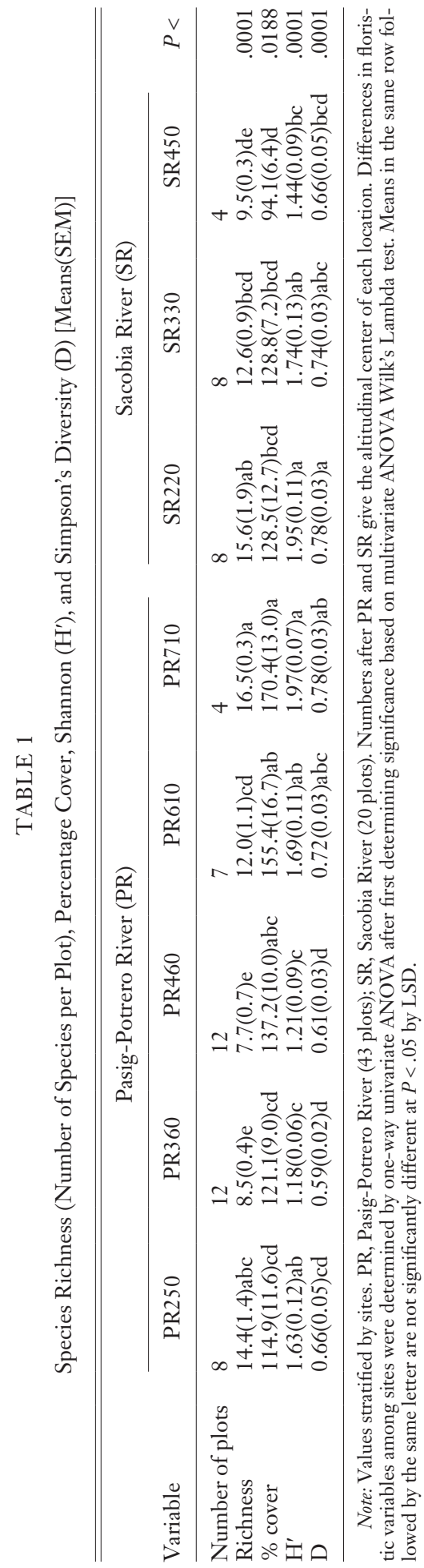

Simpson's diversity (D) patterns were similar to those of $\mathrm{H}^{\prime}$, ranged from 0.595 to 0.783 $(F=6.18$, edf $=55, P<.0001)$, and fell into four groups. Unlike H', D of the lowest SR site was greater than that of the highest PR site. Mean D was also higher along the SR (mean $\mathrm{D}=0.741$ ) than along the PR (mean $\mathrm{D}=0.648, t=-3.27, P<.0001)$. Both $\mathrm{H}^{\prime}$ and $\mathrm{D}$ revealed that diversity was the least at midelevation sites on the PR.

\section{Growth Form and Exotic/Native Relations}

We compared changes in the percentage cover of the common species individually (Table 2) and by growth forms (Figure 2). Parasponia rugosa was the only dominant tree species. Though the extent of its cover was most evident in PR and at higher elevations, it was prevalent throughout the study area. Buddleja asiatica Lour. was the only widespread shrub species, and it occurred more often on PR and increased in cover with elevation.

Large rhizomatous grasses were abundant and were dominated by Saccharum spontaneum L. The higher elevations were also commonly colonized by Miscanthus floridulus (Labill.) Warb. Percentage cover for the large-grass growth form was generally higher than for the trees because the three subordinate largegrass species exhibited substantial cover in some plots. In contrast, the nine subordinate tree species were rare throughout the study area.

Exotic vines were common at lower elevations in both rivers. Centrosema molle Mart. ex Benth. was the most abundant and widespread vine. Calopogonium mucunoides Desv. extended from the alluvial fan into the midelevation sites on both rivers. Mikania scandens Willd. was sparsely distributed and was the only exotic vine that was dominant at the highest PR sites. Macroptilium atropurpureum (DC) Urb. was the least abundant of the five vines; it was absent from SR and sporadic on PR.

Small grasses were common but were never dominant. Pennisetum setaceum (Forsk.) Chiov. and Melinis repens (Willd.) Zizka were found in all eight locations. Eragrostis tenella 
TABLE 2

Percentage Cover of Common Species across Sites (Means)

\begin{tabular}{|c|c|c|c|c|c|c|c|c|}
\hline \multirow[b]{2}{*}{ Species } & \multicolumn{5}{|c|}{ Pasig-Potrero River } & \multicolumn{3}{|c|}{ Sacobia River } \\
\hline & PR250 & PR360 & PR460 & PR610 & PR710 & SR220 & SR330 & SR450 \\
\hline \multicolumn{9}{|l|}{ Woody trees and shrubs } \\
\hline Buddleja asiatica & 0 & 0.19 & 0.78 & 3.19 & 2.85 & 0 & 0.28 & 0.35 \\
\hline Leucaena leucocephala & 1.89 & 0 & 0 & 0 & 0 & 1.04 & 3.02 & 0 \\
\hline Parasponia rugosa & $9.71 b$ & $56.1 \mathrm{a}$ & $58.6 \mathrm{a}$ & $62.2 \mathrm{a}$ & $60.5 \mathrm{a}$ & $31.1 \mathrm{ab}$ & $37.0 \mathrm{ab}$ & $26.9 \mathrm{ab}$ \\
\hline \multicolumn{9}{|l|}{ Vines } \\
\hline Calopogonium mucunoides & 3.8 & 1.38 & 3.81 & 0 & 0 & 5.36 & 0.75 & 0 \\
\hline Centrosema molle & $3.86 \mathrm{ab}$ & $1.18 \mathrm{~b}$ & $0 \mathrm{~b}$ & $0 \mathrm{~b}$ & $0 \mathrm{~b}$ & $6.97 \mathrm{a}$ & $6.40 \mathrm{a}$ & $0 \mathrm{~b}$ \\
\hline Desmodium cf. incanum & $4.04 \mathrm{ab}$ & $0.25 \mathrm{~b}$ & $0 \mathrm{~b}$ & $0 \mathrm{~b}$ & $0 \mathrm{~b}$ & $12.5 \mathrm{a}$ & $2.85 \mathrm{ab}$ & $0 \mathrm{~b}$ \\
\hline $\begin{array}{l}\text { Macroptilium } \\
\text { atropurpureum }\end{array}$ & $1.56 \mathrm{ab}$ & $0 \mathrm{~b}$ & $0 \mathrm{~b}$ & $0 \mathrm{~b}$ & $3.08 \mathrm{a}$ & $0 \mathrm{~b}$ & $0 \mathrm{~b}$ & $0 \mathrm{~b}$ \\
\hline Mikania scandens & $0.75 b$ & $0.17 \mathrm{~b}$ & $0.83 \mathrm{~b}$ & $2.74 b$ & $23.7 \mathrm{a}$ & $0.5 b$ & $4.56 \mathrm{~b}$ & $0.65 b$ \\
\hline \multicolumn{9}{|l|}{ Large grasses } \\
\hline Miscanthus floridulus & $0 \mathrm{c}$ & $0 \mathrm{c}$ & $2.80 \mathrm{c}$ & $7.30 \mathrm{~b}$ & $5.10 \mathrm{bc}$ & 0 & $11.1 \mathrm{a}$ & $5.57 \mathrm{bc}$ \\
\hline Phragmites karka & 0.58 & 0 & 0 & 0.31 & 0 & 1.04 & 2.00 & 0 \\
\hline Saccharum spontaneum & 61.3 & 45.5 & 53.0 & 35.2 & 30.3 & 43.2 & 33.6 & 43.9 \\
\hline \multicolumn{9}{|l|}{ Small graminoids } \\
\hline Eragrostis tenella & $0.75 \mathrm{~b}$ & $\mathrm{ob}$ & $0 \mathrm{~b}$ & $0.39 \mathrm{~b}$ & $0 \mathrm{~b}$ & $6.35 \mathrm{a}$ & $0 \mathrm{~b}$ & ob \\
\hline Imperata cylindrical & $0 \mathrm{~b}$ & $0 \mathrm{~b}$ & $0 \mathrm{~b}$ & $2.21 \mathrm{a}$ & $0 \mathrm{~b}$ & $0.82 \mathrm{ab}$ & $2.63 \mathrm{a}$ & $0.65 \mathrm{ab}$ \\
\hline Melinis repens & 6.86 & 7.62 & 3.07 & 11.47 & 3.05 & 3.90 & 0.90 & 1.87 \\
\hline Pennisetum setaceum & 0.80 & 3.40 & 2.35 & 3.21 & 1.00 & 1.19 & 1.03 & 0.08 \\
\hline Pogonatherum crinitum & 0 & 0 & 0.73 & 2.27 & 4.58 & 0 & 6.91 & 4.90 \\
\hline \multicolumn{9}{|l|}{ Forb species } \\
\hline Chromolaena odorata & 7.46 & 1.83 & 4.61 & 6.66 & 5.72 & 1.77 & 3.42 & 4.25 \\
\hline Conyza albida & $0 \mathrm{c}$ & $0.72 \mathrm{bc}$ & $0.98 \mathrm{bc}$ & $3.85 \mathrm{a}$ & $3.05 \mathrm{ab}$ & $0.1 \mathrm{c}$ & $0.25 \mathrm{c}$ & $0.60 \mathrm{bc}$ \\
\hline Crotalaria pallida & $2.34 \mathrm{a}$ & $0.83 \mathrm{~b}$ & $0 \mathrm{~b}$ & $0 \mathrm{~b}$ & $0 \mathrm{~b}$ & $1.44 \mathrm{ab}$ & $0.2 \mathrm{~b}$ & $0 \mathrm{~b}$ \\
\hline Desmodium tortuosum & $0.16 \mathrm{ab}$ & $0.33 \mathrm{ab}$ & $0.47 \mathrm{ab}$ & $0 \mathrm{~b}$ & $0 \mathrm{~b}$ & $1.95 \mathrm{a}$ & $0.48 \mathrm{ab}$ & $0 \mathrm{~b}$ \\
\hline Hyptis suaveolens & $0.66 \mathrm{ab}$ & $0.03 \mathrm{~b}$ & $0.78 \mathrm{ab}$ & $0 \mathrm{~b}$ & $0 \mathrm{~b}$ & $0.48 \mathrm{ab}$ & $1.98 \mathrm{a}$ & $0 \mathrm{~b}$ \\
\hline Lindenbergia philippensis & $0.04 b$ & $0 \mathrm{~b}$ & $0.5 \mathrm{ab}$ & $0.23 \mathrm{~b}$ & $1.93 \mathrm{a}$ & $0 \mathrm{~b}$ & $0.8 \mathrm{ab}$ & $1.25 \mathrm{ab}$ \\
\hline Tridax procumbens & 2.34 & 0.33 & 1.75 & 1.07 & 0.97 & 0.65 & 0.31 & 0 \\
\hline \multicolumn{9}{|l|}{ Ferns } \\
\hline Nephrolepis birsutula & ob & $0 \mathrm{~b}$ & $0.33 \mathrm{~b}$ & $2.89 a$ & $2.38 \mathrm{a}$ & $0 b$ & $0.97 \mathrm{ab}$ & $0 \mathrm{~b}$ \\
\hline $\begin{array}{l}\text { Pityrogramma } \\
\text { calomelanos }\end{array}$ & $0 \mathrm{c}$ & $0.29 \mathrm{c}$ & $1.14 b c$ & $7.31 \mathrm{ab}$ & $13.0 \mathrm{a}$ & $0 \mathrm{c}$ & $1.40 \mathrm{bc}$ & $3.23 \mathrm{bc}$ \\
\hline Totals & 113.6 & 121.1 & 137.4 & 155.7 & 176.6 & 122.2 & 130.3 & 94.1 \\
\hline
\end{tabular}

Note: Numbers after PR and SR give the altitudinal center of each location. Differences among sites were determined by ANOVA, followed by Bonferroni comparisons $(P<.05)$. Only common species listed; for all species see Appendix. Means in the same row followed by the same letter are not significantly different at $P<.05$ by LSD.

(L.) Roem. \& Schult. and Imperata cylindrica (L.) Beauv. were more common in the SR, and Melinis repens was more common in the PR. Pogonatherum crinitum Kunth was found in both river canyons but was restricted to the mid- to high elevations. This small grass is a dominant early colonizer of near-vertical surfaces on the canyon walls.

Although several forb species were common, none was dominant. The exotic Chro- molaena odorata (L.) R. M. King \& H. Rob. was the most abundant and the only forb present in every location. Conyza albida Willd. ex Spreng. was more common at higher elevations, and Crotalaria pallida Aiton, Desmodium tortuosum (Sw.) DC, and Hyptis suaveolens (L.) Poit. were common at lower elevations and absent from the highest elevations.

The two exotic fern species were also absent from the lowest elevations. Pityrogramma 

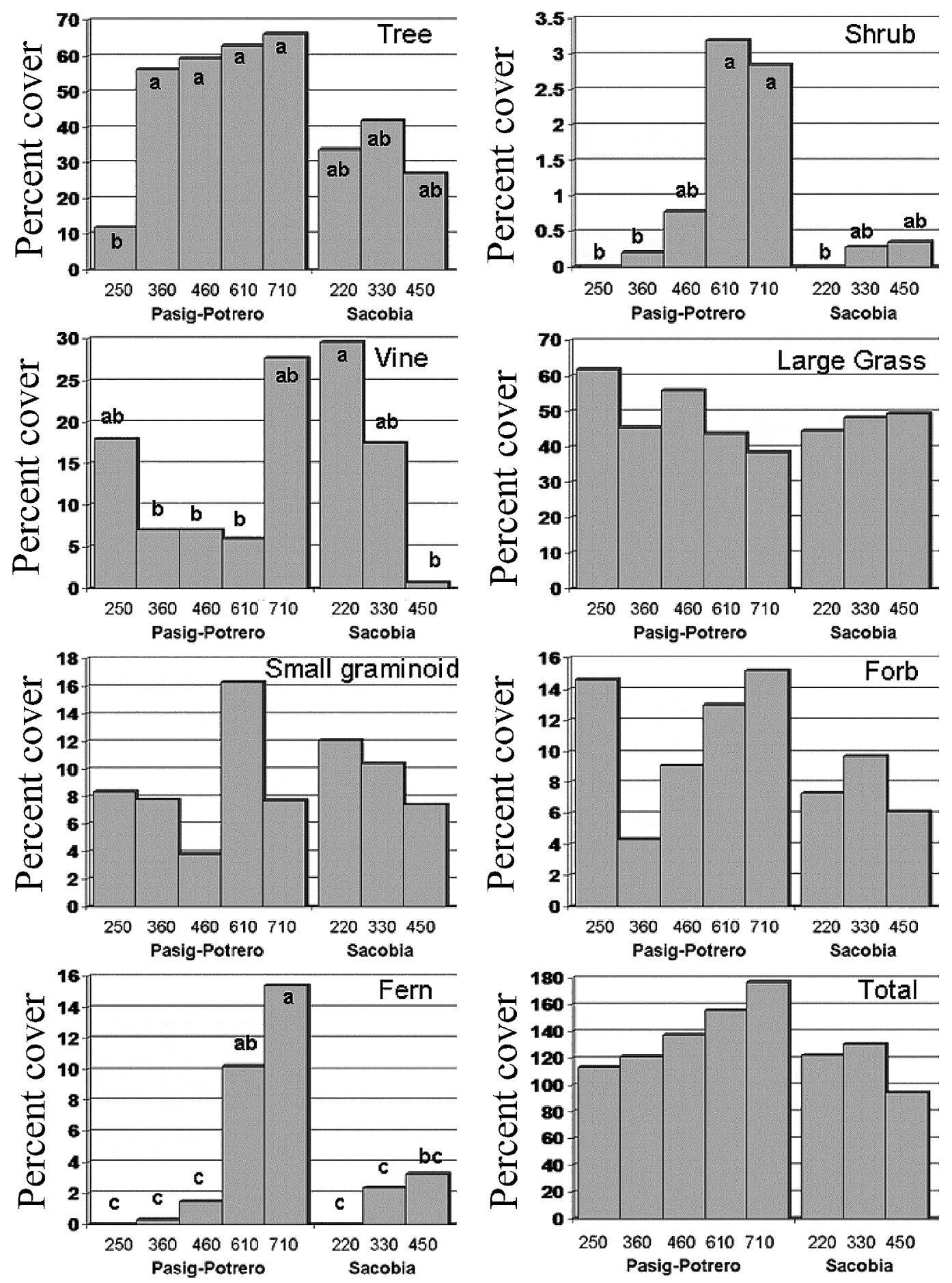

Figure 2. Cover of various growth form categories and total vegetation cover for five Pasig-Potrero and three Sacobia River sites. Differences among sites were determined by ANOVA, followed by Bonferroni comparisons. The same letter links means that are not significantly different at $P<.05$. 
TABLE 3

Partial Regression Coefficients \pm SEM for Multiple Linear Regression Models Fitted to Test the Hypothesis That Various Environmental Variables Influenced Species Richness (Number of Species per Plot), Percentage Cover, Shannon $\left(\mathrm{H}^{\prime}\right)$, and Simpson's Diversity $(\mathrm{D})$

\begin{tabular}{|c|c|c|c|c|}
\hline Variable & Cover & Richness & $\mathrm{H}^{\prime}$ & D \\
\hline Elevation & ns & $\begin{array}{c}0.10173^{* * *} \\
\pm 0.01588\end{array}$ & $\begin{array}{l}0.00635^{* * *} \\
\pm 0.00176\end{array}$ & $\begin{array}{l}0.00118^{*} \\
\pm 0.00052\end{array}$ \\
\hline Percentage rock cover & $\begin{array}{l}-0.69657^{\text {** }} \\
\pm 0.22660\end{array}$ & ns & ns & ns \\
\hline Slope & $\begin{array}{c}0.54243^{*} \\
\pm 0.28468\end{array}$ & ns & ns & ns \\
\hline Aspect & ns & ns & ns & ns \\
\hline Distance to canyon edge & $\begin{array}{c}0.15027^{*} \\
\pm 0.08176\end{array}$ & ns & ns & ns \\
\hline Distance to water channel & ns & ns & ns & ns \\
\hline Distance to human settlement & $\begin{array}{c}0.00638^{* *} \\
\pm 0.00163\end{array}$ & ns & $\begin{array}{c}0.00021^{\text {** }} \\
\pm 0.00007\end{array}$ & $\begin{array}{l}0.00006^{* *} \\
\pm 0.00002\end{array}$ \\
\hline Distance to alluvial fan & ns & ns & ns & ns \\
\hline Distance to caldera rim & ns & $\begin{array}{l}4.18153^{* * *} \\
\pm 0.61850\end{array}$ & $\begin{array}{c}0.42208^{* * *} \\
\pm 0.06319\end{array}$ & $\begin{array}{l}0.09331^{* * *} \\
\pm 0.01883\end{array}$ \\
\hline
\end{tabular}

${ }^{*} P<.05$.

** $P<.01$.

*** $P<.001$.

calomelanos (L.) Link was the most abundant fern and exhibited the strongest positive association with the elevation gradient.

Thirty-four of the 58 species were exotic, mostly in the Fabaceae and Asteraceae families. Although richness of exotic species exceeded that of native species, combined cover of all exotic species accounted for only $31.9 \%$ of the total vegetation cover.

\section{Dominant Species}

This landscape on the east flanks of Mount Pinatubo was dominated by the large grass Saccharum spontaneum and the woody tree Parasponia rugosa (combined cover mean $=$ $86 \%)$. At the plot level, these two taxa appeared to be inversely related. Therefore, a general linear model was fitted to test their association after adjusting for the differences between the rivers. The model was significant $(F=3.29$, edf $=60, P<.0441)$, and the negative slope $($ mean $=-0.208 \pm 0.099, P=.0399)$ did not differ between the two rivers. Therefore, the rate of decline in Parasponia cover as
Saccharum cover increased was significant and similar among all sites in both rivers and all elevations.

\section{Environmental Control of Cover and Structure}

Multiple linear regression models indicated that the environmental variables we measured were able to significantly explain vegetation cover, richness, $\mathrm{H}^{\prime}$, and $\mathrm{D}$. Changes in plot cover were positively correlated with surface slope and negatively correlated with surface rockiness (Table 3). Plot cover also increased with distance to the canyon edge or human settlement. Plot richness correlated with elevation and distance to the caldera, as revealed by highly significant positive partial regression coefficients. Our two synthetic estimates of diversity were positively associated with elevation, distance to human settlement, and distance to the caldera. The surface aspect, distance to the running channel, and distance to the alluvial fan were not correlated with any of the response variables within the context of our multiple linear regressions. 
DISCUSSION

\section{Elevation}

The influence of elevation on the vegetation cover $15 \mathrm{yr}$ after the eruption was partly mediated by surface stability as related to elevation. Surfaces in the highest elevations of the PR were the first to stabilize (Gran and Montgomery 2005) and exhibited the greatest plant cover in 2006 (Table 1, Figure 3). Midelevations have continued to generate sediments from unstable, high canyon walls and shifting surfaces. Lower elevations have continued to receive abundant sediment deposits arriving primarily during high-discharge events that transfer media from the midelevations.

Elevation also influenced the relative abundance of exotic species. The highest and lowest sites on both canyons supported roughly the same number of native species, but the lowest sites had more than twice as many exotic species as the highest sites. This elevation effect was mediated by greater human activity in the lower elevations. A case study in Hong Kong (Leung et al. 2009) lends support for our association of human activity and exotic species diversity in these Pinatubo canyons. They found that after centuries of anthropogenic disturbances, a greater number of exotic plant species was directly related to corridors of greater human impact and less-traveled sites were still relatively free of alien invasions.

Our highest PR sites were within the transition from lowland to montane forest habitat. Vegetation in montane habitats is partly influenced by cloud cover and aerosol water deposits, and the lower montane range occurs at ca. $600 \mathrm{~m}$ asl in this mountain range (Brosius 1990). Surfaces in this second habitat zone may have had access to a broader range of potential propagules than surfaces in sites restricted to lowland forest habitat.

That elevation influenced our response variables in the $P R$ more so than in the SR may be due to our limited altitudinal range of the SR river system. The extremities of our SR plots represented only a $230 \mathrm{~m}$ elevation gradient across $6.3 \mathrm{~km}$, whereas our PR plots extended along a $470 \mathrm{~m}$ elevation gradient across $11.3 \mathrm{~km}$. Therefore, the diversity of surface stability and altitudinal habitat zonation was greater for the PR.

In comparison, vegetation cover on Mount St. Helens declined up all slopes because posteruption surfaces were stable and therefore of similar age, and developmental processes slowed with elevation (del Moral 2007). Therefore, the manner in which elevation interacts with recovering Mount Pinatubo vegetation appears to be more complex than with recovering Mount St. Helens vegetation.

\section{River Comparisons}

The upper SR watershed was severed from lower elevations during an October 1993 storm that filled the upper SR canyon (Gran and Montgomery 2005). This disconnected upper watershed was thereafter captured by the PR. We hypothesized that floristic similarity between the two river systems would be high because of this shared history of the upper watershed and because of their close proximity.

The dominance of Parasponia rugosa and Saccharum spontaneum dwarfed cover of the third-ranked species, the exotic grass Melinis repens, and obscured differences in the growth form spectra between the rivers. The inverse relationship of these two dominant taxa was also similar for the two rivers. These observations support our hypothesis that initial vegetation on the rivers would be similar.

The manner in which exotic species assembled with native species differed between the rivers. At the large scale, exotic plant cover accounted for $31 \%$ of the PR total cover and $33 \%$ of the SR total cover. Therefore, the relationship between general exotic and native plant cover of these two rivers was remarkably similar. However, the individual species that provided the exotic plant cover of each river were highly contrasting. For example, Mikania scandens was dominant in the highest PR elevation and accounted for $41 \%$ of the exotic plant cover. This species was rare and never accounted for more than $6 \%$ of the exotic plant cover in the SR sites. Rather, exotic 

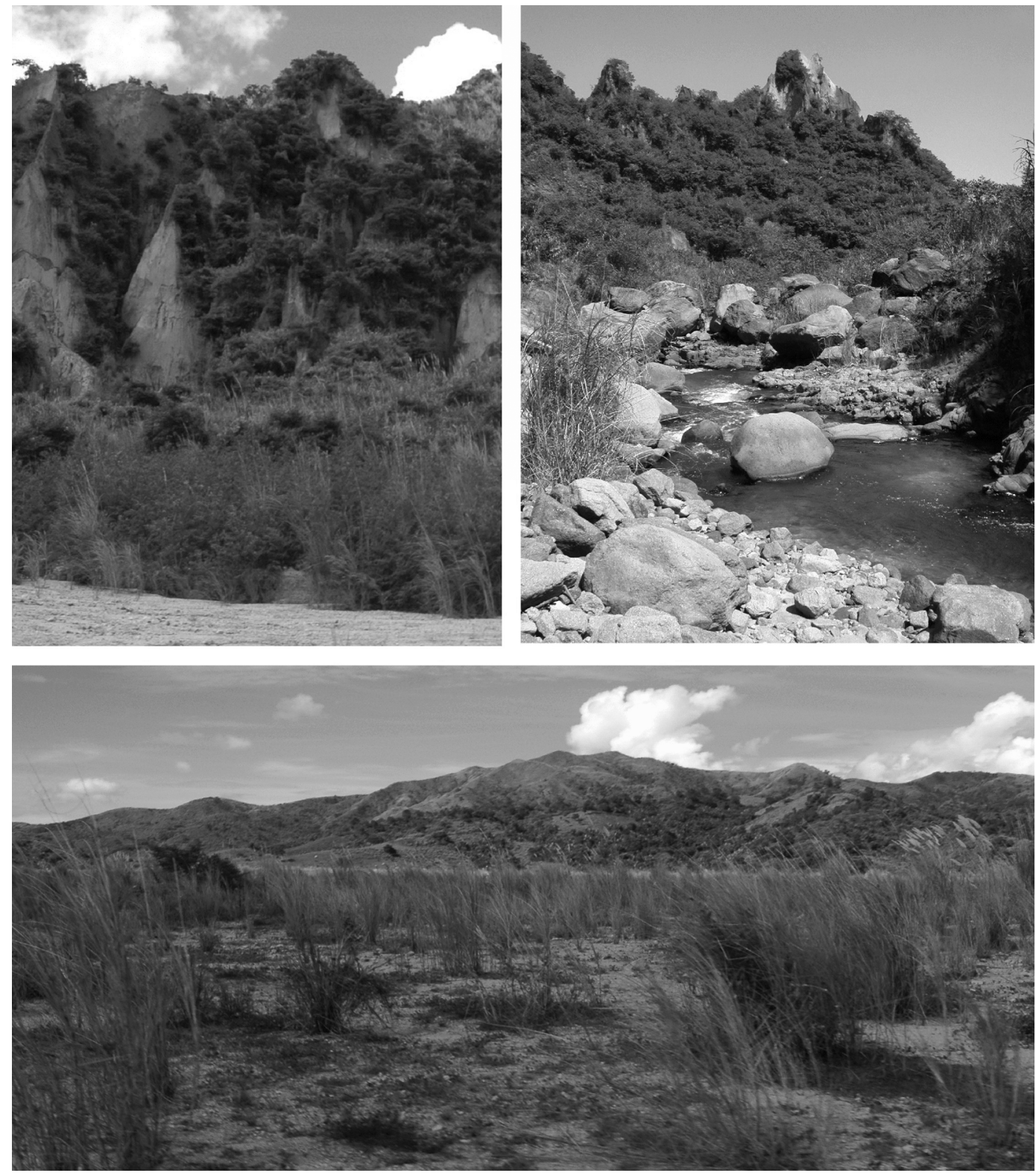

Figure 3. Physiognomy of the riparian systems on the east flanks of Mount Pinatubo in 2006. Bottom: Below the alluvial fan at $200 \mathrm{~m}$ asl the canyon is wide and vegetated surfaces are younger on average. Top, left: At midelevations the canyon walls are tall and unstable. Surfaces near the channel are barren and water is usually laden with sediments. Top, right: The highest elevations of our study at 700+ $\mathrm{m}$ asl have narrow canyons, the oldest stabilized surfaces, and the greatest plant cover within the landscape of the study. The channel is armored with large stones and water is relatively free of sediments. 
plant cover of the SR sites comprised a cocktail of species with none revealing overt dominance.

Total species richness was higher in the PR than in the SR. Several complementary explanations account for this difference. First, the greater altitudinal and longitudinal environmental gradient may contribute to higher species richness on the PR landscape. Second, ultimate stabilization of all PR geomorphological surfaces has occurred at a faster pace because the SR lost sediment-transport capacity in 1993. Indeed, lahars on the PR were common through 1997, but in the SR they were recorded as recently as 2002 (Gran and Montgomery 2005). Third, observed animal seed dispersers of the SR were domesticated livestock restricted to the lowest elevations, but observed animal seed dispersers of the PR were mostly wild species that entered and exited the river canyon at all elevations.

A second difference between the two canyon systems occurred at the plot level, with plot species richness being higher in the SR than in the PR. The PR experiences intense human activity below the alluvial fan but lacks a concentration of human settlement within the bounds of our survey, whereas a constellation of homes was scattered along both sides of the SR near our lowest elevation. Furthermore, the entire SR canyon has been subjected to ecotourism traffic associated with the springs at the highest elevation of the river. The abundance of human activity below the alluvial fan on both rivers has generated similar plot richness at the lowest elevation of each river, but the greater amount of human activity on the SR may be responsible for the SR's greater plot richness in the midelevation plots above the alluvial fan (Table 1).

A third difference between the two canyons was the greater average $\mathrm{H}^{\prime}$ and $\mathrm{D}$ within the SR plots than in the PR plots. Following initial assembly, competitive exclusion, patterns of propagule supply, or altered microsites may have led to stronger dominance in the PR. The SR plots with lower dominance (higher D) may have experienced greater disturbance after initial deposition because disturbance usually reduces competition from dominant species and reduces exclusionary processes (Cadotte 2007). This further supports the argument that physical recovery in the PR is farther along than in the SR.

A close look at the patterns of growth form categories among the sites revealed more differences between the rivers. For example, the manner in which fern and shrub cover related to elevation was similar for the two river systems, with both exhibiting a general increase with elevation. Alternatively, tree cover was highest in the highest PR elevation but was not influenced by elevation in the SR. Moreover, $\mathrm{PR}$ vine cover was greatest in the highest elevation but SR vine cover was greatest in the lowest elevation.

\section{Plant-Mediated Succession}

The absence of quantitative data gathered soon after the eruption forced our longitudinal approach. Saito et al. (2002) and Oba et al. (2004) reported that the grasses Saccharum and Melinis repens and the legumes Calopogonium mucunoides and Centrosema molle were common on PR surfaces by 1999-2000. These general observations are important but do not allow a meaningful comparison with current vegetation. Therefore, our detailing of the vegetation at $15 \mathrm{yr}$ after the eruption provides a critical baseline for future studies of ecosystem recovery.

One unambiguous comment can be made about Madulid's (1992) listing of Parasponia rugosa (as Trema philippinensis) as an endemic that was at risk of extinction following Mount Pinatubo's eruption. In contrast to that prediction, this taxon has emerged as a major pioneering species on the mountain and will undoubtedly serve as a prominent driver of future changes in vegetation patterns at the landscape level. This result underscores how primary succession is often unpredictable.

Our survey encountered more exotic species than native species. Here, as on many new surfaces (MacDonald et al. 1991), the exotic species will likely influence the course of succession (Dassonville et al. 2007). Unfortunately, Mount Pinatubo demonstrates the increasing globalization of the biota. Studies of tropical volcanoes have contributed greatly to island biogeography (Whittaker and Fernán- 
dez Palacios 2007) and to understanding long-term succession (e.g., Aplet et al. 1998). The continued study of succession on new surfaces on Mount Pinatubo will improve our understanding of how exotic species alter succession from a barren start and how landscape factors affect the rate and the direction of developing flora.

Concern about the influence of two of the exotic species on future succession may be warranted. Chromolaena odorata was the only forb found in all eight sites, and its ability to acquire dominance when introduced to new locations is well documented (McFadyen 2003). Recent work indicates that its root exudates reduce growth of sympatric taxa by stimulating abundance of the soil pathogen Fusarium spp. (Mangla et al. 2008). Similarly, the exotic Pennisetum setaceum was found in all of our sites, and its invasion of native forests on the island of Hawaili has negatively impacted resource acquisition and use by native tree species (Cordell and Sandquist 2008). Moreover, Kueffer et al. (2010) included $P$. setaceum in a short list of species that have proved to be most consistently invasive dominants across a range of island groups. We suggest active management of these aggressive exotic species for ecological restoration if future vegetation surveys reveal an increase in their abundance.

The dominance of Parasponia and large grasses tended to vary inversely at the fine scale. This inverse dominance in growth form will shape the spatial patterns of vegetation during continued recovery. The effect may be mediated by several factors. First, disparity in development of soil microbe communities will partly regulate future plant diversity (van der Heijden et al. 2008). For example, Parasponia is the only known nonlegume that nodulates in the presence of rhizobial symbionts (Lafay et al. 2006), and chemistry of its substrates will diverge from substrates supporting large grasses in 2006. Later, Parasponia may become susceptible to competition from species that can use nitrogen more effectively, as was found by Walker et al. (2003), who showed that the nitrogen-fixing Coriaria arborea facilitated growth of other species. Second, Parasponia stands are attractive to birds for roosting and foraging, but the grasses are not as suitable for roosting of most avian seed dispersers in the region. Third, the availability of soil surface for accepting immigrating seeds and enabling new recruits is substantial under the Parasponia trees, but the clumping growth habit of the large grasses confers a preemptive exclusion of incoming seeds from the soil surface. The widespread dominance of these two growth forms exhibiting contrasting chemical, physical, and biological characteristics suggests that successional trajectories will diverge.

As succession proceeds, competitive exclusion will remove some marginal species, but species better attuned to local conditions should establish (cf. del Moral and Lacher 2005). If these river systems on Mount Pinatubo follow patterns observed on other volcanoes, species diversity eventually will increase dramatically (e.g., Whittaker and Fernández Palacios 2007). Liana species are widespread components of most Philippine forests. For example, the liana growth form accounted for $17.1 \%$ of the taxa in one recent Leyte Island forest inventory (Langenberger et al. 2006). This growth form was completely lacking from the landscape we studied on the east flanks of Mount Pinatubo after $15 \mathrm{yr}$ of recovery. Therefore, we expect the increased diversity in vegetation to include liana species in the coming years.

\section{Other Volcanoes}

Many tropical ecosystems have formed in response to natural disasters (cf. Langenberger et al. 2006, del Moral and Walker 2007), so detailed studies of recovery from such disturbances are vital to understand the developmental processes that shape contemporary tropical forests. Yet few studies of vegetation recovery have been conducted on tropical lowland volcanoes, and most of these have been conducted on materials ejected from the cone (del Moral and Grishin 1999).

This survey of early succession shows that, despite major environmental differences, there are many processes similar to those operating on temperate-zone volcano landscapes. Landscape effects such as elevation 
and geographic position were highly associated with vegetation change, as they were on Mount St. Helens (del Moral and Lacher 2005). Despite these similarities, the speed of vegetation recovery on Mount Pinatubo is noteworthy, with dense cover of species occurring in less than $15 \mathrm{yr}$. This rapid recolonization contrasts with processes on lahars (Walker and del Moral 2003, Weber et al. 2006), pumice (Grishin et al. 1996), scoria (Tsuyuzaki 1995), and lavas in cool temperate (del Moral and Grishin 1999) or warm temperate (Kamijo et al. 2002) habitats.

Primary succession after the famous 1883 eruption of Krakatau has been detailed by several groups. Several taxa in our study were reported on its substrates (Tagawa et al. 1985, Whittaker et al. 1989). Those workers showed that fern-dominated and grass communities (Saccharum, Imperata) were common, but forests (with Ficus) gradually replaced those grasses.

A few qualitative studies suggested that Mount Pinatubo has similarities to regional volcanoes. Parasponia rugosa also dominated lahars on Mount Kelut, Java (Becking 1982). A survey of vegetation shortly after the 1911 eruption of Taal in southwestern Luzon stated that only Saccharum could thrive in the devastated terrain (Yates 1914, Brown et al. 1917). Buot (2008) described woody vegetation on the active Mount Mayon volcano in southeastern Luzon. Most of his sites were at elevations above our upper limits and were affected by agriculture, but two small plots below $600 \mathrm{~m}$ asl had 29 woody species. Our more intensive sampling protocol found only 10 woody species. Despite substantial vegetation cover and despite the success of Parasponia, $15 \mathrm{yr}$ of succession is insufficient for most woody species to colonize and develop on Mount Pinatubo's stabilized surfaces.

\section{Lessons}

This overview of developing vegetation on Mount Pinatubo demonstrates that vegetation cover and initial species assembly in lowland wet tropical systems can be rapid, relatively small elevation and geographic gradients affect many floristic variables at the landscape level, and a retrospective understanding of succession is impossible without earlier empirical studies. These two river canyons exhibit many similarities 15 yr after the eruption, but also some distinct differences. We believe that the disparities in elevation gradient, pace of geophysical recovery, and human influence account for the differences.

This study has clarified several factors that may be used to form predictions about continued succession and inform experimental designs. The spatial and temporal patterns of ongoing vegetation recovery on the east flanks of Mount Pinatubo will continue to be heavily influenced by factors associated with elevation and the form and extent of human activity. As the canyons become more deeply dissected and complex, heterogeneity of microclimates will increase and will begin to influence plant establishment and vigor at a small scale. As vegetation becomes better established, plant cover will begin to exert more influence on the physical processes that enhance surface stability. Continued vegetation recovery will conform to trajectories defined by the taxa and assemblies that currently dominate at the local level. Some factors, such as current similarity in dominant species, may lead to convergence of vegetation characteristics in the PR and SR canyons. However, other factors, including current floristic differences, the disparate elevation gradient, the ongoing anthropogenic disturbances that are greater in the SR, and the fact that geophysical recovery of the PR is more advanced than that of SR may promote divergence. The highest PR site exhibited several unique features, including the oldest stabilized surfaces and greatest plant cover, richness, and $\mathrm{H}^{\prime}$. Moreover, this site was the only site of the study where exotic cover was dominated by a single taxon. The differences of this site may serve to form predictions about vegetation characteristics at higher elevations that are closer to the caldera.

The greatest value of our 2006 survey is that we have established a baseline that allows comparison of future vegetation changes, which in turn will enable comparisons of relative growth of these native and exotic species as succession proceeds. Active management may be warranted if alien species increase in 
abundance or cover, especially for the invasive taxa that are known to engineer changes in landscape ecology in other invaded sites.

\section{ACKNOWLEDGMENTS}

We thank Joe Armstrong, Leonardo Co, Joy Everett, Surrey Jacobs, Nontu Ntuli, Lynn Raulerson, and Karen Wilson for species identifications; Chris Newhall for helping to understand the geomorphic surfaces; Captain Boy Tanglao for field guidance, providing local plant nomenclature, and companionship during the fieldwork; and Jonathan Titus and Karen Gran for improving the manuscript.

\section{Literature Cited}

Aplet, G. H., R. F. Hughes, and P. M. Vitousek. 1998. Ecosystem development on Hawaiian lava flows: Biomass and species composition. J. Veg. Sci. 9:17-26.

Becking, J. H. 1982. $\mathrm{N}_{2}$-fixing tropical nonlegumes. Pages 109-146 in Y. R. Dommergues and H. G. Diem, eds. Microbiology of tropical soils and plant productivity. W. Junk Publishers, London.

Brosius, J. P. 1990. After Duwagan: Deforestation, succession, and adaptation in upland Luzon, Philippines. Center for South and Southeast Asian Studies, University of Michigan.

Brown, W. H., E. D. Merrill, and H. S. Yates. 1917. The revegetation of Volcano Island, Luzon, P.I. since the Taal eruption. Philipp. J. Sci. 12:177-248.

Buot, I. E. 2008. Dominant woody species of Mount Mayon forest landscape, Luzon, Philippines. Flora Malesiana Bull. 13:364368.

Cadotte, M. W. 2007. Competitioncolonization trade-offs and disturbance effects at multiple scales. Ecology 88:823829.

Cordell, S., and D. R. Sandquist. 2008. The impact of an invasive African bunchgrass (Pennisetum setaceum) on water availability and productivity of canopy trees within a tropical dry forest in Hawaii. Funct. Ecol. 22:1008-1017.
Dassonville, N., S. Vanderhoeven, W. Gruber, and P. Meerts. 2007. Invasion by Fallopia japonica increases topsoil mineral nutrient concentrations. Ecoscience 14:230-240.

del Moral, R. 2007. Limits to convergence of vegetation during early primary succession. J. Veg. Sci. 18:479-488.

del Moral, R., and S. Y. Grishin. 1999. The consequences of volcanic eruptions. Pages 137-160 in L. R. Walker, ed. Ecosystems of disturbed ground. Ecosystems of the World Series. Elsevier Science, Amsterdam, Netherlands.

del Moral, R., and I. L. Lacher. 2005. Vegetation patterns 25 years after the eruption of Mount St. Helens, Washington. Am. J. Bot. 92:1948-1956.

del Moral, R., and L. R. Walker. 2007. Environmental disasters, natural recovery and human responses. Cambridge University Press, Cambridge, United Kingdom.

Douglass, D. H., and R. S. Knox. 2005. Climate forcing by the volcanic eruption of Mount Pinatubo. Geophys. Res. Lett. 32:L05710.

Forster, P. M. D., and M. Collins. 2004. Quantifying the water vapour feedback associated with post-Pinatubo global cooling. Clim. Dyn. 23:207-214.

Gran, K. B., and D. R. Montgomery. 2005. Spatial and temporal patterns in fluvial recovery following volcanic eruptions: Channel response to basin-wide sediment loading at Mount Pinatubo, Philippines. Geol. Soc. Am. Bull. 117:195-211.

Grishin, S. Y., R. del Moral, P. Krestov, and V. P. Verkholat. 1996. Succession following the catastrophic eruption of Ksudach volcano (Kamchatka, 1907). Vegetatio 127:129-153.

Gu, L., D. D. Baldocchi, S. C. Wofsy, J. W. Munger, J. J. Michalsky, S. P. Urbanski, and T. A. Boden. 2003. Response of a deciduous forest to the Mount Pinatubo eruption: Enhanced photosynthesis. Science (Washington, D.C.) 299:2035-2038.

International Plant Names Index. 2009. http://www.ipni.org (accessed 4 May 2010).

Kamijo, T., K. Kitayama, A. Sugawara, S. Urushimichi, and K. Sasai. 2002. Primary 
succession of the warm-temperate broadleaved forest on a volcanic island, Miyakejima, Japan. Folia Geobot. 37:71-91.

Kueffer, C., C. C. Daehler, C. W. TorresSantana, C. Lavergne, J.-Y. Meyer, R. Otto, and L. Silva. 2010. A global comparison of plant invasions on oceanic islands. Perspect. Plant Ecol. Evol. Syst. 12:145-161.

Lafay, B., E. Bullier, and J. J. Burdon. 2006. Bradyrhizobia isolated from root nodules of Parasponia (Ulmaceae) do not constitute a separate coherent lineage. Int. J. Syst. Evol. Microbiol. 56:1013-1018.

Langenberger, G., K. Martin, and J. Sauerborn. 2006. Vascular plant species inventory of a Philippine lowland rainforest and its conservation value. Biodivers. Conserv. 15:1271-1301.

Leung, G. P. C., B. C. H. Hau, and R. T. Corlett. 2009. Exotic plant invasion in the highly degraded upland landscape of Hong Kong, China. Biodivers. Conserv. 18:191-202.

MacDonald, I. A. W., C. Thebaud, W. A. Strahm, and D. Strasberg. 1991. Effects of alien plant invasion on native vegetation remnants on Réunion (Mascarene-Islands, Indian Ocean). Environ. Conserv. 18:5161.

Madulid, D. A. 1992. Mount Pinatubo: A case of mass extinction of plant species in the Philippines. Silliman J. 36:113-121.

- 2001. A dictionary of Philippine plant names. Vol. 1. Local name-scientific name. The Bookmark, Inc. Makati City, Philippines.

Major, J. J., R. J. Janda, and A. S. Daag. 1996. Watershed disturbance and lahars on the east side of Mount Pinatubo during the mid-June 1991 eruptions. Pages 895-919 in C. G. Newhall and R. S. Punongbayan, eds. Fire and mud: Eruptions and lahars of Mount Pinatubo, Philippines. University of Washington Press, Seattle.

Mangla, S., Inderjit, and R. M. Callaway. 2008. Exotic invasive plant accumulates native soil pathogens which inhibit native plants. J. Ecol. 96:58-67.

McFadyen, R. C. 2003. Chromolaena in Southeast Asia and the Pacific. Pages 130-144 in
H. Costa, C. Piggins, C. J. Cruz, and J. J. Fox, eds. Agriculture: New directions for a new nation-East Timor. Australian Centre for International Agricultural Research Proceedings No. 113, Canberra.

Newhall, C. G., and R. S. Punongbayan, eds. 1996. Fire and mud: Eruptions and lahars of Mount Pinatubo, Philippines. University of Washington Press, Seattle.

Oba, H., N. Shinozaki, H. Oyaizu, K. Tawaraya, T. Wagatsuma, W. L. Barraquio, and M. Saito. 2004. Arbuscular mycorrhizal fungal communities associated with some pioneer plants in the lahar area of Mt. Pinatubo, Philippines. Soil Sci. Plant Nutr. 50:1195-1203.

Pierson, T. C., A. S. Daag, P. J. Delos Reyes, M. T. M. Regalado, R. U. Solidum, and B. S. Tubianosa. 1996. Flow and deposition of post eruption hot lahars on the east side of Mount Pinatubo, July-October 1991. Pages 921-950 in C. G. Newhall and R. S. Punongbayan, eds. Fire and mud: Eruptions and lahars of Mount Pinatubo, Philippines. University of Washington Press, Seattle.

Saito, M., K. Minamisawa, and W. Barraquio. 2002. Significance of symbiotic microorganisms in revegetation process in lahar area of Mt. Pinatubo. Paper 1275. Trans. 17th World Congr. Soil Sci., 14-21 August 2002, Bangkok, Thailand.

Sasaki, R., M. Yoshida, Y. Ohtsu, M. Miyahira, H. Ohta, M. Watanabe, and S. Suzuki. 2003. Soil formation of new lahar materials derived from Mount Pinatubo. I. Physical and chemical properties of new lahar materials and soils formed by old lahar materials. Soil Sci. Plant Nutr. 49:575-582.

Tagawa, H., E. Suzuki, T. Partomihardjo, and A. Suriadarma. 1985. Vegetation and succession on the Krakatau Islands, Indonesia. Vegetatio 60:131-145.

Thornton, I. W. B. 1996. Krakatau: The destruction and reassembly of an island ecosystem. Harvard University Press, Cambridge, Massachusetts.

. 2007. Island colonization: The origin and development of island communities. Cambridge University Press, Cambridge, United Kingdom. 
Tsuyuzaki, S. 1995. Vegetation recovery patterns in early volcanic succession. J. Plant Res. 108:241-248.

van der Heijden, M. G. A., R. D. Bardgett, and N. M. van Straalen. 2008. The unseen majority: Soil microbes as drivers of plant diversity and productivity in terrestrial ecosystems. Ecol. Lett. 11:296310.

USDA Germplasm Resources Information Network. 2009. http://www.ars-grin.gov (accessed 4 May 2010).

Walker, L. R., B. D. Clarkson, W. B. Silvester, and B. R. Clarkson. 2003. Colonization dynamics and facilitative impacts of a nitrogen-fixing shrub in primary succession. J. Veg. Sci. 14:277-290.

Walker, L. R., and R. del Moral. 2003. Primary succession and ecosystem rehabilitation. Cambridge University Press, Cambridge, United Kingdom.

Weber, M. H., K. S. Hadley, P. M. Frenzen, and J. F. Franklin. 2006. Forest development following mudflow deposition,
Mount St. Helens, Washington. Can. J. For. Res. 36:439-449.

Whittaker, R. J., M. B. Bush, N. M. Asquith, and K. Richards. 1992. Ecological aspects of plant colonization of the Krakatau Islands. GeoJournal 28:201-211.

Whittaker, R. J., M. B. Bush, T. Partomihardjo, and K. Richards. 1989. Plant recolonization and vegetation succession on the Krakatau Islands, Indonesia. Ecol. Monogr. 59:59-123.

Whittaker, R. J., and S. H. Jones. 1994. The role of frugivorous bats and birds in the rebuilding of a tropical forest ecosystem, Krakatau, Indonesia. J. Biogeogr. 21:245-258.

Whittaker, R. J., and J. M. Fernández Palacios. 2007. Island biogeography: Ecology, evolution, and conservation. 2nd ed. Oxford University Press, Oxford, United Kingdom.

Yates, F. C. 1914. The pioneer vegetation of Taal Volcano. Philipp. J. Sci. 9:391434.

\section{Appendix}

Name, Authority, Family, Growth Form, River Drainages (Pasig-Potrero, P; Sacobia, S), and Status (Taxon Is Exotic or Native)

\begin{tabular}{|c|c|c|c|c|}
\hline Species Name and Authority & Family & Growth Form & River & Status \\
\hline Aeschynomene americana $\mathrm{L}$. & Fabaceae & Forb & $\mathrm{P}, \mathrm{S}$ & Exotic \\
\hline Ageratum boustonianum Mill. & Asteraceae & Forb & $\mathrm{P}, \mathrm{S}$ & Exotic \\
\hline Ageratum L. sp. & Asteraceae & Forb & $\mathrm{P}$ & Exotic \\
\hline Alysicarpus vaginalis (L.) DC. & Fabaceae & Forb & $\mathrm{P}$ & Native \\
\hline Bidens alba DC. & Asteraceae & Forb & $\mathrm{P}$ & Exotic \\
\hline Buddleja asiatica Lour. & Buddlejaceae & Shrub & $\mathrm{P}, \mathrm{S}$ & Native \\
\hline Bulbostylis barbata (Rottb.) C. B. Clarke & Cyperaceae & Small graminoid & $\mathrm{P}$ & Native \\
\hline Calopogonium mucunoides Desv. & Fabaceae & Vine & $\mathrm{P}, \mathrm{S}$ & Exotic \\
\hline Canscora diffusa (Vahl) R. Br. ex Roem. \& Schult. & Gentianaceae & Forb & $\mathrm{P}, \mathrm{S}$ & Native \\
\hline Centrosema molle Mart. ex Benth. & Fabaceae & Vine & $\mathrm{P}, \mathrm{S}$ & Exotic \\
\hline Chloris barbata (L.) Sw. & Poaceae & Small graminoid & $\mathrm{P}, \mathrm{S}$ & Exotic \\
\hline Cbromolaena odorata (L.) R. M. King \& H. Rob. & Asteraceae & Forb & $\mathrm{P}, \mathrm{S}$ & Exotic \\
\hline Conyza albida Willd. ex Spreng. & Asteraceae & Forb & $\mathrm{P}, \mathrm{S}$ & Exotic \\
\hline Conyza bonariensis (L.) Cronquist & Asteraceae & Forb & $\mathrm{P}$ & Exotic \\
\hline Crassocephalum crepidioides (Benth.) S. Moore & Asteraceae & Forb & $\mathrm{P}, \mathrm{S}$ & Exotic \\
\hline Crotalaria pallida Aiton & Fabaceae & Forb & $\mathrm{P}, \mathrm{S}$ & Exotic \\
\hline Cyperus polystachyos Rottb. & Cyperaceae & Small graminoid & $\mathrm{P}, \mathrm{S}$ & Exotic \\
\hline Dactyloctenium aegyptium (L.) P. Beauv. & Poaceae & Small graminoid & $\mathrm{P}, \mathrm{S}$ & Native \\
\hline Desmodium cf. incanum DC. & Fabaceae & Vine & $\mathrm{P}, \mathrm{S}$ & Exotic \\
\hline Desmodium tortuosum (Sw.) DC. & Fabaceae & Forb & $\mathrm{P}, \mathrm{S}$ & Exotic \\
\hline Eleusine indica (L.) Gaertn. & Poaceae & Small graminoid & $\mathrm{P}, \mathrm{S}$ & Exotic \\
\hline Eragrostis tenella (L.) Roem. \& Schult. & Poaceae & Small graminoid & $\mathrm{P}, \mathrm{S}$ & Native \\
\hline
\end{tabular}


Appendix (continued)

\begin{tabular}{|c|c|c|c|c|}
\hline Species Name and Authority & Family & Growth Form & River & Status \\
\hline Ficus blepharostoma Warb. & Moraceae & Tree & $\mathrm{S}$ & Native \\
\hline Ficus L. spp. ${ }^{a}$ & Moraceae & Tree & $\mathrm{P}, \mathrm{S}$ & Native \\
\hline Gliricidia sepium (Jacq.) Walp. & Fabaceae & Tree & $\mathrm{P}, \mathrm{S}$ & Exotic \\
\hline Hyptis suaveolens (L.) Poit. & Lamiaceae & Forb & $\mathrm{P}, \mathrm{S}$ & Exotic \\
\hline Imperata cylindrica (L.) Beauv. & Poaceae & Small graminoid & $\mathrm{P}, \mathrm{S}$ & Native \\
\hline Kyllinga brevifolia Rottb. & Cyperaceae & Small graminoid & $\mathrm{P}$ & Native \\
\hline Lantana camara $\mathrm{L}$. & Verbenaceae & Forb & $\mathrm{P}, \mathrm{S}$ & Exotic \\
\hline Leucaena leucocephala (Lam.) de Wit & Fabaceae & Tree & $\mathrm{P}, \mathrm{S}$ & Exotic \\
\hline Lindenbergia philippensis (Cham.) Benth. & Orobanchaceae & Forb & $\mathrm{P}, \mathrm{S}$ & Native \\
\hline Macroptilium atropurpureum (DC.) Urb. & Fabaceae & Vine & $\mathrm{P}$ & Exotic \\
\hline Maoutia setosa Wedd. & Urticaceae & Tree & $\mathrm{P}$ & Native \\
\hline Melastoma malabatbricum L. & Melastomataceae & Tree & $\mathrm{S}$ & Native \\
\hline Melinis repens (Willd.) Zizka & Poaceae & Small graminoid & $\mathrm{P}, \mathrm{S}$ & Exotic \\
\hline Mikania scandens Willd. & Asteraceae & Vine & $\mathrm{P}, \mathrm{S}$ & Exotic \\
\hline Mimosa diplotricha C. Wright ex Sauv. & Fabaceae & Forb & $\mathrm{P}, \mathrm{S}$ & Exotic \\
\hline Mimosa pudica L. & Fabaceae & Vine & $\mathrm{P}, \mathrm{S}$ & Exotic \\
\hline Miscanthus floridulus (Labill.) Warb. & Poaceae & Large grass & $\mathrm{P}, \mathrm{S}$ & Native \\
\hline Muntingia calabura $\mathrm{L}$. & Muntingiaceae & Tree & $\mathrm{P}, \mathrm{S}$ & Exotic \\
\hline Musa errans Teodoro & Musaceae & Forb & $\mathrm{P}$ & Native \\
\hline Nephrolepis hirsutula (Forst.) Presl. & Davalliaceae & Fern & $\mathrm{P}, \mathrm{S}$ & Exotic \\
\hline Parasponia rugosa Blume ${ }^{b}$ & Ulmaceae & Tree & $\mathrm{P}, \mathrm{S}$ & Native \\
\hline Passiflora foetida $\mathrm{L}$ & Passifloraceae & Vine & $\mathrm{S}$ & Exotic \\
\hline Pennisetum setaceum (Forsk.) Chiov. & Poaceae & Small graminoid & $\mathrm{P}, \mathrm{S}$ & Exotic \\
\hline Phaseolus Tourn. spp. & Fabaceae & Vine & $\mathrm{P}, \mathrm{S}$ & Exotic \\
\hline Phragmites karka (Retz.) Trin. ex Steud. & Poaceae & Large grass & $\mathrm{P}, \mathrm{S}$ & Native \\
\hline Pipturus arborescens (Link) C. B. Rob. & Urticaceae & Tree & $\mathrm{P}, \mathrm{S}$ & Native \\
\hline Pityrogramma calomelanos (L.) Link & Adiantaceae & Fern & $\mathrm{P}, \mathrm{S}$ & Exotic \\
\hline Pogonatherum crinitum Kunth & Poaceae & Small graminoid & $\mathrm{P}, \mathrm{S}$ & Native \\
\hline Saccharum spontaneum L. & Poaceae & Large grass & $\mathrm{P}, \mathrm{S}$ & Native \\
\hline Solanum nigrum $\mathrm{L}$. & Solanaceae & Forb & $\mathrm{P}$ & Exotic \\
\hline Spathoglottis plicata Blume & Orchidaceae & Forb & $\mathrm{P}, \mathrm{S}$ & Native \\
\hline Thysanolaena maxima Kuntze & Poaceae & Large grass & $\mathrm{P}$ & Native \\
\hline Tithonia diversifolia (Hemsl.) A. Gray & Asteraceae & Forb & $\mathrm{S}$ & Exotic \\
\hline Tridax procumbens L. & Asteraceae & Forb & $\mathrm{P}, \mathrm{S}$ & Exotic \\
\hline Zebneria indica (Lour.) Keraudren & Cucurbitaceae & Vine & $\mathrm{P}$ & Native \\
\hline
\end{tabular}

Note: Authors are from the International Plant Names Index (http://www.ipni.org/index.html); cf., provisional name; sp., one species; spp., two or more species.

${ }^{a}$ Ficus spp. includes two species known locally as Binunga and Tabui.

${ }^{b}$ Parasponia rugosa nomenclature follows USDA Germplasm Resources Information Network. 
